\title{
Policy Regimes and Economic Accountability in Latin America
}

\author{
Ryan E. Carlin \\ Georgia State University \\ rcarlin@gsu.edu \\ Timothy Hellwig \\ Indiana University \\ thellwig@indiana.edu
}

To be published in Comparative Political Studies

\begin{abstract}
The shifts from state-led development to neoliberalism in Latin America have prompted debates on the quality of democracy. While most discussions focus on responsiveness, we examine how economic policy regimes influence accountability. We argue that the policy regime matters for policy responsibility Citizens' ability to hold executive to accounts strengthens where policy regimes are more statist and weakens where policy regimes are more market oriented. Time-series analyses of policy orientations, economic conditions, and presidential approval in 18 countries support this proposition, while complementary analyses at the individual-level support claims that a responsibility mechanism links policy regimes to accountability. Study findings imply that by embracing heterodox policy regimes, recent Latin American executives have improved accountability compared to the era in which the "Washington Consensus" held sway.
\end{abstract}


The Latin American debt crisis precipitated one of history's quickest, boldest, and geographically broadest waves of economic reform. Political and social disruptions in its wake quickly prompted scholars to reassess two core elements of democratic theory - representation and accountability in contexts of economic flux (Borón, 1996; Domínguez, 1998; Morgan Kelly, 2003; O’Donnell, 1994; Weyland, 2004; Stokes 2001). Whereas the rise of the Latin American Left fueled an impressive follow-on research agenda on the link between economic policy regimes and representation (inter alia, Baker, 2009; Baker and Greene, 2011; Levitsky and Roberts, 2011), and the Great Recession stoked renewed interest in the political economy of financial crises in the region (e.g. Steinberg et al., 2015; Steinberg, 2017), the mixed and highly nuanced conclusions about the implications of policy change for economic accountability received less attention.

The effects of policy regimes on accountability warrant fresh examination on the following grounds. First, we lack consensus. Early work struggled to reconcile retrospective voting theory with the short-run discretion publics accorded to leaders after "Washington Consensus" stabilization and structural adjustment packages (Buendía, 1996; Echegaray and Elordi, 2001; Gervasoni, 1999; Weyland, 1996). Now the short run has become the long run. And typical political business-cycle spending to appease reforms' losers has morphed into an array of policy regimes marrying neoliberal principles to state interventions meant to soften their negative externalities (e.g., Avelino et al., 2005; Kurtz and Brooks, 2008). Statist and neoliberal dogmatisms have given way to the pragmatism of mixed regimes in the "post-Washington Consensus" (Birdsall and Fukuyama, 2011). Do such policy regimes influence how citizens hold political executives to accounts? The jury is out.

A second reason we revisit the policy-democracy link is its conspicuous absence in recent works on accountability in Latin America. Studies of the backlash to neoliberalism dealt primarily 
with protests that interrupted Latin American presidencies (e.g. Arce and Bellinger, 2007; Kurtz, 2004; Pérez-Liñán, 2007). The few studies that analyze the less dramatic, but continual, linkage between the economy and presidential approval (Arce, 2003; Arce and Carrión, 2010; Morgan Kelly, 2003) place little weight on the role of distinct policy regimes. Tests of conditional accountability largely probe factors orthogonal to economic structure (e.g. Campello and Zucco, 2016; Carlin et al., 2015; De Ferrari,2015; Gélineau, 2007; Johnson and Schwindt-Bayer, 2009; Rosas and Manzetti, 2015; Samuels, 2004; Zechmeister and Zizumbo-Colunga, 2013). Given the salience of economic policy reforms among publics, we know surprisingly little about their implications for the public's ability to reward presidents for economic gains and punish them for losses.

A third warrant for this reexamination concerns the ties between a president's public standing and democratic governance. Just as popularity shapes U.S. presidents' legislative agendas (CanesWrone and De Marchi, 2002) and policy choices (Canes-Wrone et al., 2001), it helps Latin American presidents pass bills (Calvo, 2007), succeed in inter-branch bargaining (MartínezGallardo, 2012), alter term limits (Corrales, 2016), and finish their terms (Pérez-Liñán, 2007). Insomuch as public evaluations of incumbents matter for democratic outcomes, it pushes us to ask the related question of how policy regimes affect accountability.

This investigation also carries theoretical payoffs for unpacking the mass politics consequences of political-economic systems. Do changes in how economies work matter for how democracy works? Our starting point is simple: economic policy regimes determine the state's role in the economy and, in turn, condition public perceptions of incumbent responsibility for economic outcomes. Neoliberal regimes, which shift the burden of economic management from the state to the private sector, should thus undermine accountability, whereas more interventionist policy 
regimes, which put the levers of policy control firmly in the state's hands, should strengthen it. Asymmetry results. Incumbents who govern under free markets may not see their popularity respond weakly to economic expansion, but they risk less punishment for poor performance. Likewise, governing in more statist policy regime means that even small performance upticks can translate into higher approval ratings.

We next discuss how economic policy regimes shape policy responsibility which, in turn, contributes to how citizens evaluate policymakers. We then introduce the Latin American case as our context of interest. We show that neoliberal and statist policy orientations varied both over time and across the regions' economies. Examining their influence on accountability, we find that policy regimes condition the impact of economic growth on presidential approval: statist policy directions sharpen ties between the economy and popularity; neoliberal models weaken them. Additional analyses substantiate that this result derives from views on policy responsibility in different policy regimes. The conclusion discusses study implications for democracy in Latin America and, more generally, for the limits of economic accountability.

\section{Economic Responsibility and Accountability under Distinct Policy Regimes}

By accountability we mean "the electorate's capacity to reward or sanction incumbent politicians" (Samuels, 2004, 425). If elections and mass mobilization are potent but rare opportunities to hold executives accountable (Manin et al., 1999), then public evaluations between elections approximate a continual accountability mechanism (Johnson and Schwindt-Bayer, 2009; Morgan Kelly, 2003). Policy strategies shape the prospects for economic accountability in two steps. The first concerns the state's economic role. The larger it is, the more responsibility the public assigns leaders for economic management. Step two relates policy regimes and public economic 
responsibility attributions to leader evaluations. Under more liberal economic strategies economic responsibility attributions translate into incumbent popularity less easily than under more interventionist strategies.

By way of illustration, in pure statist models the state and not the market plays the economic protagonist, promoting production (via credit, subsidies, etc.) and picking sectoral winners (via tariffs, commodity boards, etc.). Economic management is 'job one,' and employment, wage, and prices flow directly from government policies. The public, in turn, can connect economic outputs to incumbent policy. In contrast, orthodox neoliberalism rejects economic management by the state as anathema. Market fundamentalism removes the government's fingerprints from economic outcomes by eliminating import barriers, neo-corporatist structures, wage floors, price controls, reducing spending, etc. In such contexts, the public should attribute less responsibility for economic performance to incumbents and, perhaps, attribute it elsewhere.

More commonly, of course, policy lies between statist and neoliberal extremes. Heterodoxy need not imply policy incoherence. Just as post-war Europe's bargain of "embedded liberalism" coherently blended domestic interventionism with a liberal approach abroad (Ruggie, 1982), Latin America's "embedded neoliberal" regimes promote free trade and capital flows and deploy supplyside interventions (Kurtz and Brooks, 2008). These run the gamut from labor-market policies like training programs and public employment, to industrial policies that encourage exporters to invest in technology, diversify, and reach new market segments, to an array of public resource commitments $(i b i d)$. So while heterodox policy regimes require a more economically active state than neoliberal ones, their economic outcomes are more at the mercy of market forces than under statism. Thus, in mixed regimes we expect citizens to assign executives a judicious degree of responsibility for the economy_less than under statism but more than under neoliberal orthodoxy. 
In sum, economic policy regimes should influence accountability by altering the mass public's attributions of government responsibility for the economy. Whereas liberalization should decrease the responsibility the public assigns the government for economic output, state intervention should increase it. The extent to which the public holds leaders to accounts for the economy should, in turn, fall with neoliberalism and rise with statism. Between these poles, heterodox regimes ought to induce moderate degrees of economic accountability. Evidence consistent with these expectations would underscore the consequences of political-economic models and the quality of democracy. Below we assess these claims empirically.

\section{Policy Regimes in Latin America, 1980 to Present: Description and Measurement}

Moving from theoretical abstraction to empirical observation, we measure policy regimes in Latin America since the 1980s and test whether they condition economic accountability. Within three decades policymakers across the region crafted — to varying degrees and at varying rates — three distinct economic policy regimes: ISI statism, orthodox neoliberalism, and heterodoxy. The heterogeneity in policy regimes over time and cross-nationally, not to mention lingering doubts as to their effects on accountability, makes the region a useful testing ground.

The genesis of economic policy change in Latin America was the 1980s debt crisis spurred by the exhaustion of statist import-substitution development models. Executives in the region accepted short-term stabilization packages from the International Monetary Fund, World Bank, and Inter-American Development Bank. After these failed, they implemented neoliberal structural reforms unilaterally or via the mechanism of loan conditionality. By reducing the state's role in markets, neoliberal orthodoxy made interventionist policies such as price and capital controls, credit subsidies, and comprehensive social insurance programs undesirable or infeasible. 
Yet structural reform was uneven across policy sectors and countries, and statist policies were not swapped 1:1 for neoliberal ones. After meeting the short-run goal of stabilization, the arcs of structural reforms diverged across policy sectors and countries. Liberalization in trade, foreign investment, and privatization was aggressive but timid in taxation and labor. As Lora (2012,3) notes, "these changes involve far-reaching reforms, but they also suggest that not all the reform potential was exploited." Indeed, since the masses rejected the market's vagaries but cheered its consumptive benefits (Baker 2009), many leaders embraced heterodox strategies. Such models combine economic openness and state production promotion, welfare protections, investments in human capital formation, countercyclical spending, and supply-side interventions (Avelino et al., 2005; Kaplan, 2013; Kurtz and Brooks, 2008). Presently, heterodoxy reigns in Latin America.

We measure these policy regimes through a pair of indices tapping the degree to which the economy accords with market fundamentals and state's ability to offset negative market externalities. To start, we rely on Lora's (2012) indices of structural reform in five areas: trade, financial markets, tax reform, private sector ownership, and labor markets. The trade index gauges the removal of tariffs and other trade barriers. The financial liberalization index combines metrics of bank reserve ratios, interest rates, taxes on financial transactions, and bank supervision. The tax index looks at national tax policy legislation. The privatization index taps levels of private investment in infrastructure projects in the transport, telecommunications, energy, and water sectors, and reflects the accumulated value of the privatizations, net of nationalizations, as a percentage of GDP. Lastly, the labor market index gauges flexibility in hiring and firing, social security contributions, and minimum wage levels.

Nearly all Latin American countries made neoliberal reforms in the 1990s, especially in trade and finance, and to lesser degrees in taxes and privatization. In contrast, labor market reforms were 
fewer, more limited, and often a hodgepodge of pro-market and statist policies - a reality Lora's labor market index obscures. We address this by developing an unambiguously statist measure of reforms to worker welfare based on protections from joblessness, sickness, and old age. Specifically, the worker welfare index combines Lora's index of social security contributions and other taxes and payroll contributions with his measure of the minimum wage. ${ }^{1}$ To incorporate the state's willingness to offset negative market externalities through a broad range of fiscal interventions, following Kurtz and Brooks (2008) we include data on final government consumption as a share of GDP from the World Bank's World Development Indicators. The measure includes all government expenditures (including payrolls) save military expenditures classified as capital formation. These six indicators tap distinct orientations of economic policy regimes. We expect trade, finance, taxation, and privatization to mark neoliberal orientations, and worker welfare and government consumption to reflect statist orientations.

With annual measures available from the mid-1980s to 2009 for most of Latin America, we use dynamic factor modeling (DFM) to generate summary indexes that tap orientations to Neoliberalism and Statism across policy regimes. Found mainly in macroeconomics and psychology, applications of DFMs in political science are rare. Dynamic techniques are better suited than standard factor-analytic methods to the panel nature of our data (i.e., multiple observed

\footnotetext{
${ }^{1}$ We exclude three sub-indices of Lora's Labor Reform Index - expected costs of firing a worker, hiring flexibility, and flexibility in working hours - from our Worker Welfare index for several reasons. For one, they a qualitatively distinct from labor market reforms as social protections. Second, hiring flexibility is measured discretely, complicating index construction. Lastly, Lora's Labor Reform index loads on neither the neoliberal nor the statist policy regime dimension.
} 
indicators for multiple countries over a series of years). "Dynamic" implies that at every time point, the estimation of each index incorporates information from the entire sample of available data, thus rendering smoothed indices. We estimate the factor loadings with Tripodis and Zirogiannis' (2015) algorithm for two reasons. First, it accounts for how the indicators vary within and between countries over time. Second, it is appropriate for relatively short time dimensions ( $T$ $<50$ ). Since country-specific estimates would preclude cross-national comparison, we assume the estimated factor loadings do not differ across countries. ${ }^{2}$

Figure 1 displays our estimates of policy orientation over time for 18 Latin American and Caribbean countries. Long-dashed lines represent Neoliberalism, produced from the Lora indices for trade, finance, taxes, and privatization; high values connote orthodox neoliberal policies. Shortdashed lines reflect Statism, combining worker welfare and government consumption; high values signal the state plays a strong economic role. Together, the policy trends tell a compelling story of the political economy of Latin America. Neoliberalism shows a region-wide pro-market shift with respect to taxes, trade, finance, and regulation. However, as captured by Statism, trends in government spending and worker protections, areas in which Latin American policy makers retained or increased influence were not uniform (e.g., Kurtz and Brooks, 2008).

\footnotetext{
${ }^{2}$ Note that Tripodis and Zirogiannis' DFM algorithm is confirmatory; regression analyses with scores produced by principal components analysis produce the same results.
} 
Figure 1. Economic Policy Regimes in 18 Latin American and Caribbean Countries, 1985-2009
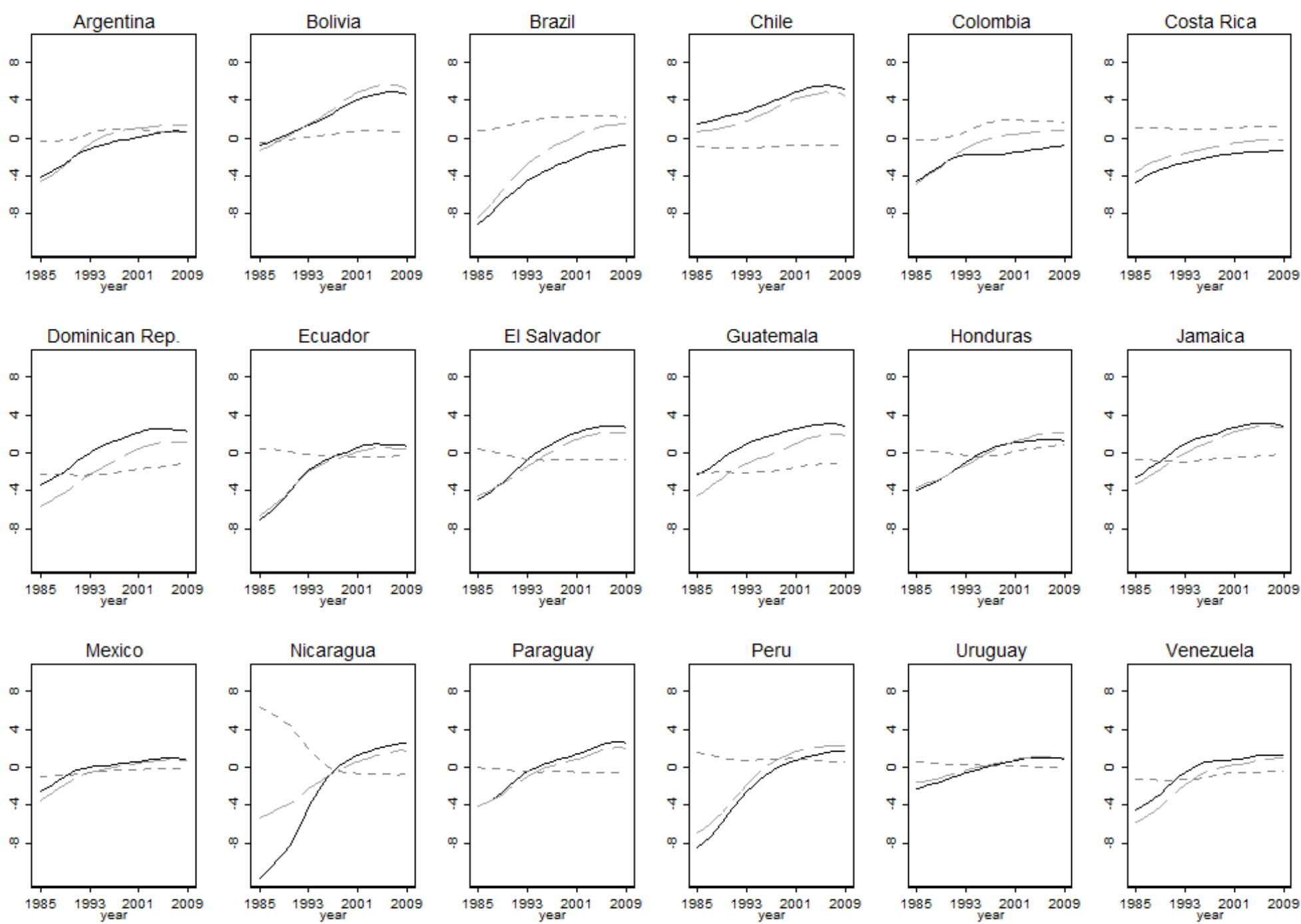

Note: Long dashes report Neoliberalism, dynamic factor scores from Lora's (2012) trade, finance, taxation, and privatization indices. Short-dashed report Statism dynamic factor scores from Worker Welfare and government consumption. Solid line is Policy Regime, equal to the difference in Neoliberalism and Statism. 
To capture a more general orientation of economic policy, we subtract Statism from Neoliberalism to produce a single summary measure for the orientation of policy. The resulting series, which we label Policy Regime, appears as the dark solid lines in Figure 1. Policy Regime's peaks and valleys are most obvious in emblematic cases such as Bolivia, Ecuador, Nicaragua, Peru, and

Venezuela where market-tilting reforms provoked instability and ushered in leaders who tempered them. Smoother liberalizing trajectories are found in Chile, Colombia, Costa Rica, Honduras, Mexico, and Uruguay. With these measures in hand, we now test the observable implications of our theory linking policy regimes and presidential approval.

\section{Data and Measures}

We test our argument by modeling the effect of economic performance on presidential approval across the range of economic policy regimes in Latin America over the last four decades. Crossnationally comparable time series data are scarce for our dependent variable, presidential approval. Differences in question wording, response sets, temporal lengths, periodicity, sample frames, etc., pose major barriers. To overcome them we collect as much presidential popularity data as possible for each country (4492 survey marginals from 139 series from the Executive Approval Database ${ }^{3}$ ) and combine them into single series based on country-specific measurement models using Stimson's (1991) dyad-ratios algorithm. ${ }^{4}$

\footnotetext{
${ }^{3}$ Www.executiveapproval.org.

4 Items take many forms, e.g., "approval", "favorability", and ratings of the president's “management", "job/work," "performance", and "image".
} 
The method assumes that to the extent a given data time series is a valid indictor of presidential approval, the ratio of any two values within the series is a relative indicator of approval. The algorithm uses all such dyadic ratios within a given series to estimate approval values at regular time intervals. To combine $N$ time series for a country $i$ into a single measure, each raw series undergoes this transformation, resulting in $N$ dyads-ratio series. If these $N$ dyads-ratio series are relative indicators of presidential approval, they should co-vary where they have temporal overlap and this common variance should tap a single latent construct - presidential approval. From this covariance, we compute validity estimates for each of $N$ input series to estimate the best single series of latent approval. Exponential smoothing on the resulting series removes random fluctuation due to sampling error and sharpens the estimates.

Evidence suggests this approach is valid and reliable. Following Erikson et al. (2002) we calculate approval as $\frac{\% \text { positive rating }}{(\% \text { positive rating }+\% \text { negative rating })} .{ }^{5}$ By excluding neutral and ambivalent responses this approach eases comparisons across series. On average, a single dimension theorized to be presidential approval, accounts for $87.56 \%$ of the variance in our measurement models, with a low of $70.83 \%$ (Mexico) and a high of $95.25 \%$ (Brazil). Most input series load highly $(\geq 0.90)$ on the latent factor. Meeting conservative criteria for confirmatory factor analysis bolsters our confidence in the validity and reliability of our measures of presidential approval.

Our primary explanatory variable gauges economic performance in terms of economic growth. Growth is the percent annual change in real GDP from the World Development Indicators,

\footnotetext{
${ }^{5}$ Measuring approval as the total percentage of positive ratings or net approval (positive rating minus negative rating) changes the results reported below very little.
} 
converted into quarterly frequencies. ${ }^{6}$ Models also contain a pair of political variables. To account for elevated approval during presidential "honeymoons", we include a series coded 1 for quarters following elections of new executives. Additionally we include a series of interventions for scandals involving the president from Pérez-Liñán (2007) and updated in Carlin et al. (2015). Appendix table A1 reports the countries, years, and quarters included in the analyses.

\section{Analysis}

We use these data to test our claim that economic policy regimes influence economic accountability, i.e. the electorate's capacity to sanction incumbents for the economy. Here we operationalize economic accountability as the impact of shocks to Growth on Approval. To assess whether policy regimes indeed condition this basic economics-popularity relationship, we pool country time-series and estimate partial adjustment autoregressive distributed lag models. Lagged dependent variables account for potential time dependence within panels. Models include country fixed-effects to account for unobserved unit heterogeneity. ${ }^{7}$ To account for differences in the

${ }^{6}$ We produce a quarterly series with the following formula: $\rho=\left[\rho(t-1) * \frac{4-\sigma(t)}{4}\right]+[\rho(t) *$ $\left.\left(\frac{\sigma(t)}{4}\right)\right]$ where $\rho$ is the annual growth rate, $\sigma$ the quarter of interest, and $t$ the year of interest (Palmer and Whitten 1999).

${ }^{7}$ Regarding dynamics, the first lag of the dependent variable sufficiently accounts for the series' autoregressive properties. Since models estimated with an additional lag are substantively identical, and the coefficient on the additional lag is insignificant, estimates in Table 1 are unbiased by residual serial correlation. Regarding cross-unit heterogeneity, debates persist about pairing 
persistence of error processes across countries, we include panel-specific auto-regressive terms (Williams and Whitten, 2011); this is especially appropriate for unbalanced panels. Unit root tests for heterogeneous panels reveal no indication of non-stationarity (Im et al., 2003) and thus suggest an autoregressive model is appropriate. Panel-corrected standard errors address any heteroskedasticity and any contemporaneously correlated disturbances the data's panel structure might induce.

Our analytical strategy is to examine a range of policy regime measures to assess the robustness of our results. Accordingly, Table 1 reports the results of six models. Model 1 is a baseline specification estimated without the policy reform index. As expected, estimates underscore the importance of political events and the economy. Presidents can expect an average bump of almost seven percentage points on their Honeymoon and a Scandal to cost them nearly three points. More germane to our study, the positive and statistically significant coefficient on Growth indicates that, ceteris paribus, strong economic performance leads citizens to rate

Table 1. Policy Reforms, the Economy, and Presidential Approval

\begin{tabular}{rrrrrrr}
\hline & M1 & M2 & M3 & M4 & M5 & M6 \\
\hline Appovalt -1 & $0.779^{* *}$ & $0.767^{* *}$ & $0.766^{* *}$ & $0.763^{* *}$ & $0.774^{* *}$ & $0.772^{* *}$
\end{tabular}

fixed effects with lagged dependent variables (Nickell, 1981; Plümper and Troeger, 2007). However, as $T$ increases, the bias fixed effects induce is minimal. Taking estimates from Table 1 Model 1 and setting $T=24$, equal to the shortest time series, the bias is approximated by $-(1+\rho) /(T-$ $1)=-0.077$, or about ten percent of the estimate on the lagged dependent variable. Nonetheless, we re-estimate Table 1 models without fixed effects and report results in Appendix Table A2 and Figure A1. As post-estimation analyses displayed in Figure A1 show, results are qualitatively identical. 


\begin{tabular}{|c|c|c|c|c|c|c|}
\hline & $(0.023)$ & $(0.023)$ & $(0.023)$ & $(0.023)$ & $(0.023)$ & $(0.022)$ \\
\hline Honeymoont & $\begin{array}{r}6.742^{* * *} \\
(1.136)\end{array}$ & $\begin{array}{r}6.716^{* *} \\
(1.130)\end{array}$ & $\begin{array}{r}6.722 * * \\
(1.128)\end{array}$ & $\begin{array}{r}6.816^{* * *} \\
(1.124)\end{array}$ & $\begin{array}{r}6.751 * * \\
(1.132)\end{array}$ & $\begin{array}{r}6.811^{* * *} \\
(1.128)\end{array}$ \\
\hline Scandalt & $\begin{array}{r}-2.712 * * \\
(1.122)\end{array}$ & $\begin{array}{r}-2.618^{* *} \\
(1.113)\end{array}$ & $\begin{array}{r}-2.545^{* *} \\
(1.112)\end{array}$ & $\begin{array}{r}-2.669 * * \\
(1.108)\end{array}$ & $\begin{array}{r}-2.636 * * \\
(1.115)\end{array}$ & $\begin{array}{r}-2.580 * * \\
(1.116)\end{array}$ \\
\hline Growtht $_{t}$ & $\begin{array}{r}0.287 * * \\
(0.077)\end{array}$ & $\begin{array}{r}0.273^{* * *} \\
(0.075)\end{array}$ & $\begin{array}{r}0.320 * * \\
(0.085)\end{array}$ & $\begin{array}{r}0.285^{* * *} \\
(0.076)\end{array}$ & $\begin{array}{r}0.282^{* * *} \\
(0.076)\end{array}$ & $\begin{array}{r}0.337 * * \\
(0.086)\end{array}$ \\
\hline Neoliberalism $_{t}$ & & $\begin{array}{r}0.636^{* * *} \\
(0.264)\end{array}$ & $\begin{array}{r}0.762 * * \\
(0.282)\end{array}$ & $\begin{array}{r}0.520 * * \\
(0.265)\end{array}$ & & \\
\hline Statism $_{t}$ & & $\begin{array}{r}-3.233 * * \\
(1.353)\end{array}$ & $\begin{array}{r}-3.485^{* *} \\
(1.348)\end{array}$ & $\begin{array}{r}-3.471 * * \\
(1.342)\end{array}$ & & \\
\hline Growth $_{t} \times$ Neoliberalism $_{t}$ & & & $\begin{array}{c}-0.107^{*} \\
(0.060)\end{array}$ & & & \\
\hline Growth $_{t} \times$ Statism $_{t}$ & & & & $\begin{array}{r}0.272 * * \\
(0.105)\end{array}$ & & \\
\hline Policy Regimet & & & & & $\begin{array}{l}0.479^{*} \\
(0.253)\end{array}$ & $\begin{array}{r}0.543 * * \\
(0.259)\end{array}$ \\
\hline Growth $_{t} \times$ Policy Regime $_{t}$ & & & & & & $\begin{array}{r}-0.114 * * \\
(0.049)\end{array}$ \\
\hline Constant & $\begin{array}{r}14.234 * * \\
(2.344)\end{array}$ & $\begin{array}{r}10.124^{* *} \\
(2.664)\end{array}$ & $\begin{array}{r}10.072 * * \\
(2.637)\end{array}$ & $\begin{array}{r}11.913 * * \\
(2.596)\end{array}$ & $\begin{array}{r}13.444 * * \\
(2.396)\end{array}$ & $\begin{array}{r}14.504^{* *} \\
(2.287)\end{array}$ \\
\hline $\mathrm{N}$ & 959 & 959 & 959 & 959 & 959 & 959 \\
\hline $\mathrm{R}^{2}$ & 0.820 & 0.820 & 0.824 & 0.828 & 0.818 & 0.825 \\
\hline
\end{tabular}

Notes: Cells report parameter estimates with panel-corrected standard errors in parentheses. Standard errors are adjusted for panel-specific AR1 processes. All models include country fixed effects. ${ }^{* *} \mathrm{p} \leq 0.05,{ }^{*} \mathrm{p} \leq 0.10$, two tailed test.

their presidents higher. While non-controversial, these results constitute the most comprehensive evidence of their kind in Latin America and thus make a unique empirical contribution. Adding our two policy regime indexes, Model 2 finds that, all else equal, popularity ratings are high under more neoliberal policy regimes and lower in more statist settings.

Remaining models test our priors regarding accountability under different economic policy regimes through interactive modeling. Model 3 specifies the effect of Growth on Approval to vary according to Neoliberalism. Per theoretical expectations, the economic policy regime matters for economic accountability. The interaction coefficient, Growth $\times$ Neoliberalism, is negative and 
precisely estimated, implying that as the policy regime's orientation shifts becomes more orthodox the relationship between economic assessments and presidential approval weakens. In Model 4 we condition the effects of Growth by Statism, and the coefficient on the interaction term is now positive. Consistent with expectations, the economy has a stronger impact on the president's standing in statist regimes than in neoliberal ones. The final two models replace these two indexes the summary Policy Regime measure (see Figure 1). Here again, as expected, the coefficient on Growth $\times$ Policy Regime in Model 6 is signed positively.

The top row of Figure 2 displays predicted changes in the (short-term) effects of a unit increase in economic conditions on presidential approval across in-sample values of Neoliberalism, Statism, and Policy Regime. Figure 2A employs Model 3 estimates to examine the effects of economic growth as Neoliberalism varies. In the absence of neoliberal policies, we observe that a positive economic shock boosts presidential job ratings, in line with conventional wisdom (Bellucci and Lewis-Beck, 2011). Yet this effect diminishes as we move from left to right on the $\mathrm{x}$-axis and policy orientation becomes more liberal. Changes in growth rates no longer register a statistically discernible influence on approval ratings when Neoliberalism surpasses a value of 1.4, or roughly the policy orientation exhibited by Argentina in 2008 or Brazil in 2007. Figure 2B displays the opposite conditioning effect of Statism on Growth's influence on Approval: as long as the policy regime is sufficiently statist, business cycles matter for executive popularity. Figure $2 \mathrm{C}$ uses Policy Regime to produce a result similar to that of Neoliberalism (Figure 2A) but slightly more precise.

\section{Figure 2. Conditional Effects of the Economy and Economic Policy Regime Orientations on Presidential Approval}


A. Table 1 Model 3

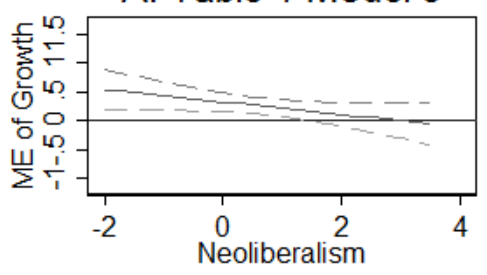

D. Table A3 Model 1

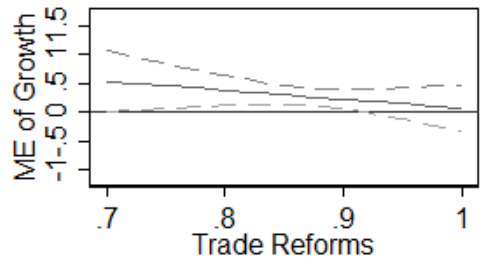

G. Table A3 Model 4

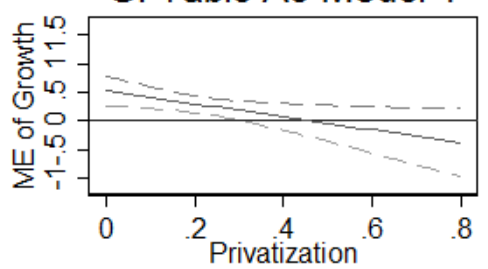

B. Table 1 Model 4

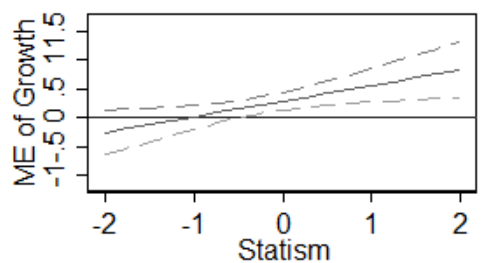

E. Table A3 Model 2



H. Table A3 Model 5

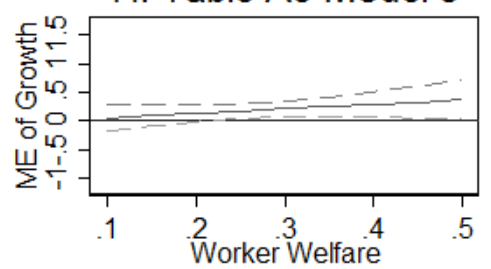

C. Table 1 Model 6

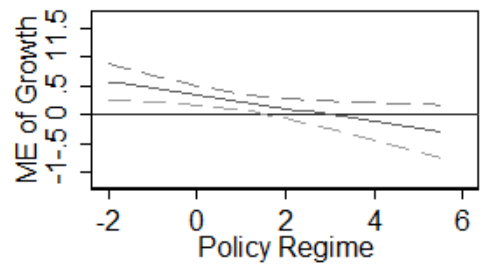

F. Table A3 Model 3

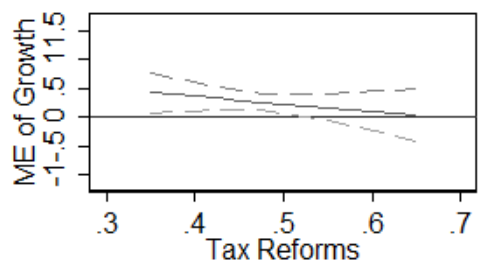

I. Table A3 Model 6

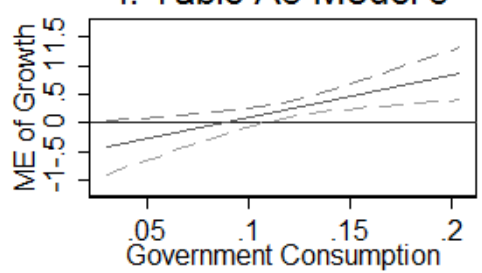

$\mathrm{x}$-axes depict in-sample values, dashed lines represent $95 \%$ confidence intervals

Notes: Graphs report marginal effects of a one-unit increase in Growth on Approval over the sample range of the conditioning factor identified on the x-axis. Dashed lines represent $95 \%$ confidence intervals. Title reflect the table and model estimates used to produce graphs.

As leaders "go neoliberal" - by opening to trade, privatizing state ventures, or dismantling capital controls - the public holds them less accountable for the economy.

Policy regimes are, of course, multifaceted, piecemeal, and can change in numerous ways. Furthermore, liberalizing reforms, such as privatization, may coincide with new social protections without trade or tax reforms even on the table. Might distinct policy levers condition economic accountability to different degrees? To answer this question, we disaggregate our summary indices into their six components, replacing the Neoliberalism and Statism indices with their 
components - the sub-indices of trade reform, financial reform, tax reform, privatization, worker welfare, and government consumption as a share of GDP — and re-estimate our interactive models.

We report model estimates in Appendix Table A3 and the resulting conditional effects in the middle and bottom rows of Figure 2. While the slopes in these graphs are not as steep as the slopes of the aggregated indexes, it is remarkable that in each of six graphs, the policy indicator registers a statistically significant impact in the anticipated direction. In the first four cases (trade reforms, financial reform, tax reform, privatization) the positive influence of economic growth on presidential popularity falls from significance once policies attain a degree of liberalization. Government consumption and pro-worker policies, by contrast, bolster the expected "economic voting" relationship. Results from these disaggregated analyses, thus, add further credence our basic argument. While the specific reforms' effects clearly differ, their interrelationships underline the appropriateness of analyzing reforms in terms of the broad strategies described above. In sum, neoliberal reforms weaken the president's accountability for the economy. Furthermore, this finding is not limited to or driven by certain indicators; rather, neoliberal and statist policy regimes constitute separate syndromes that affect economic accountability in opposing ways.

Ranging beyond contemporaneous effects, model dynamics offer insights into the long-term effects of policy reforms on economic accountability. After calculating the long-run multiplier, which depicts the full effect of a change in an exogenous variable through all subsequent quarters in the series, ${ }^{8}$ we simulate the over-time effects of economic growth on the predicted levels of

\footnotetext{
${ }^{8}$ In a Koyck model, the long-term effect of a unit increase in an independent variable is given by $\hat{\beta} /(1-\hat{\alpha})$ where $\widehat{\beta}$ is the parameter estimate of the exogenous regressor and $\hat{\alpha}$ is the estimate of
} 
presidential approval. Forecasts depict two states of the world: one in which policies are highly neoliberal, and another where they approximate a statist regime. ${ }^{9}$ Presidential approval is set to $55 \%$ and values for Honeymoon and Scandal are set at zero, their modes.

The left-hand side of Figure 3 employs estimates from Table 1 Model 6 to display the effects of economic conditions on presidential approval ratings under distinct policy regimes. Our theory predicts the public will reward presidents less for economic performance as policy skews neoliberal. And that is what we observe. Under a more neoliberal policy regime-i.e., high values on Policy Regime - a healthy economy experiencing four percent annual growth is predicted to yield but a modest increase in approval ratings of about 2.5 points after one year (four quarters), all else equal. In contrast, in a strongly statist policy regime, a four percent growth rate would have twice the effect on Approval, boosting it around five percentage points. Thus, freeing markets dampens the role of economic performance considerations in mass assessments of political leaders. Figure $3 \mathrm{~B}$ reports the path of presidential approval when the growth rate is set to zero. In a neoliberal policy regime the effects on Approval's path is no different from the $4 \%$ growth scenario shown

the lagged dependent variable. Simulations are performed with STATA's dynsim package (Williams and Whitten, 2011).

${ }^{9}$ We set Policy Regime to its $90^{\text {th }}$ percentile in-sample value to illustrate "Neoliberalism" and to its $10^{\text {th }}$ percentile value for "Statism." 
Figure 3. Forecasting the Effects of the Economy on Presidential Approval in Two Policy Regimes
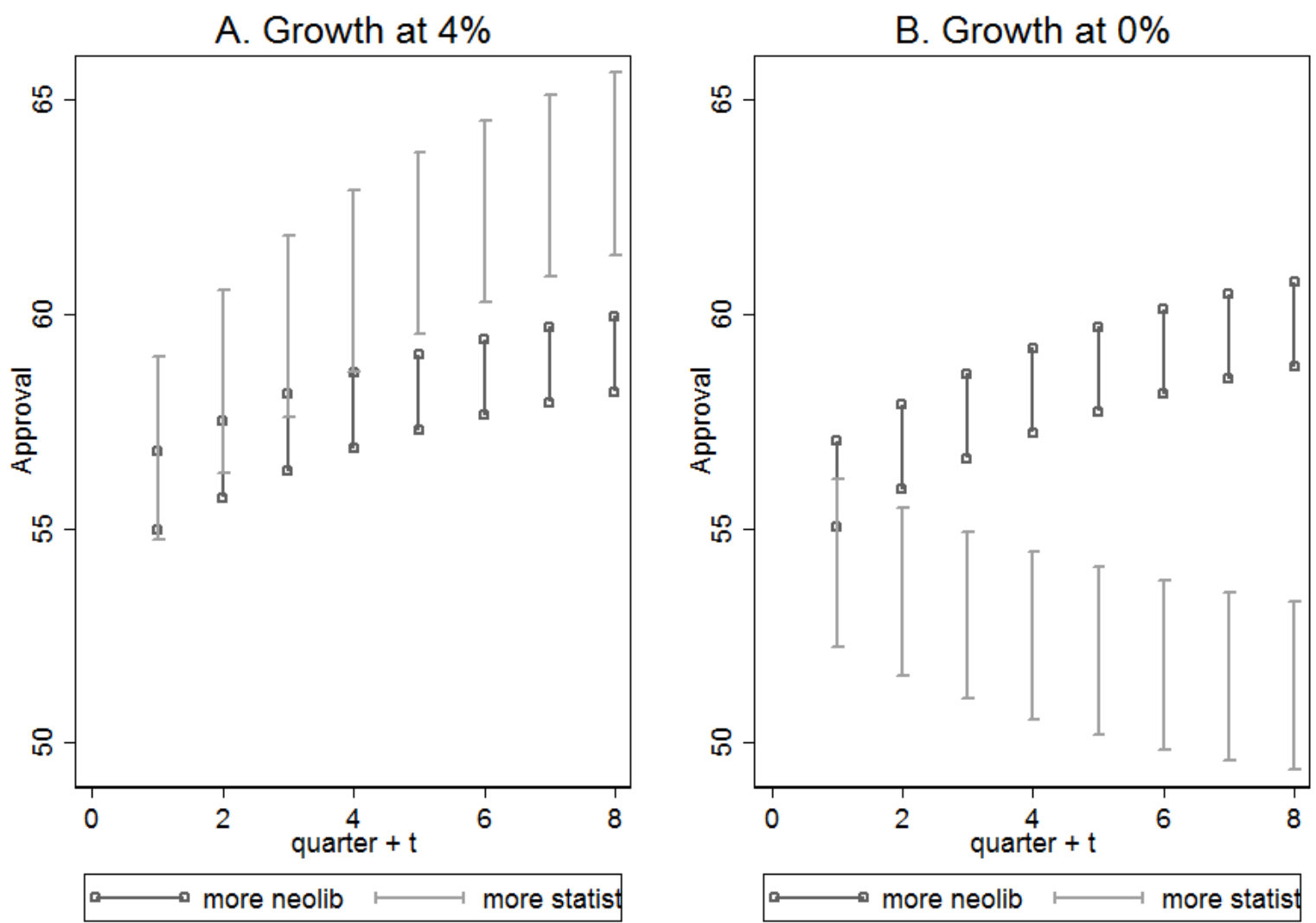

Note: Graphs produced using estimates from Table 1 Model 6. Policy Regime is set to its $90^{\text {th }}$ percentile in-sample value to illustrate a "more neoliberal" scenario and to its $10^{\text {th }}$ percentile value for the "more statist" case. Vertical bars represent 95\% confidence intervals.

in Figure 3A. Neoliberal policies effectively remove economic performance as a basis of the president's public standing. It is only when the policy regime tilts in a statist direction that the president takes a significant hit in popularity for overseeing stagnant conditions.

\section{Alternative Mechanisms and Measures}


Our results above suggest economic accountability depends on the structure of the policy regime. This finding is not limited to specific policy mixes but appears across a range of policy areas. To substantiate this conclusion, we perform a pair of additional analyses. First, we entertain an alternative argument: it may not be that the statist-neoliberal nature of collective policy outputs condition presidential approval but, rather, the mass political consequences of economic performance are shaped by the president's policy actions. If this were the case, then our findings would imply that presidents can strategically manipulate the direction of policy to shirk blame for a poor economy, or to claim credit for a good one. To test this alternative mechanism, we reconceive of our policy measures from levels policy orientation to changes in policy orientations. Namely, we gauge deviations in values of Neoliberalism, Statism, and Policy Regime from previous president's administration. Results appear in Appendix Table A4. They show that departures from previous administrations' policies, per se, matter for approval ratings: more neoliberal policies increasing approval and more statist policies decreasing it, all else equal. But these shifts have no influence whatsoever on the economy-approval relationship at the heart of our theory.

Second, we consider an alternative indicator of economic conditions. The single indicator we employ above, based on annual growth rates, may not encompass the entirety of economic conditions. Some argue that subjective economic evaluations perform better as an encompassing indicator for the economic signals received by the public (cf. Erikson et al., 2002). By collapsing the disparate memories of different economic indicators into a single series, subjective measures also ameliorate issues with selecting lag specification in time series models, allowing "the relevant objective macro-economic indicators in each country to be self-weighted according to voter attitudes" (Bellucci and Lewis-Beck, 2011, 196). 
To see whether our results are robust to a subjective indicator, we construct time series measures of Consumer Confidence; Appendix Table A5 provides information on data sources. Seven indices are modeled on the University of Michigan's Index of Consumer Sentiment (ICS), which combines five questions about current and future economic conditions. Other indices use some combination of these and other questions (e.g. inflation expectations) to create indices of present conditions and future expectations that are averaged into overall consumer confidence indices. We employ the dyads-ratio algorithm described above to combine multiple indices/series in Bolivia, Brazil, Chile, Peru, and Uruguay, and to impute (and smooth) values from an index measured at varying intervals in Costa Rica. Each index in the analysis is scaled 0-100.

We re-estimate Table 1 models using Consumer Confidence in place of Growth and report results in Appendix Table A6 and Figure A2. These analysis confirm that, just as with economic growth, policy regimes serve to condition the (positive) effect of aggregated subjective economic evaluations on presidential approval, and do so in ways that are qualitatively identical to what we reported above. This is the case despite the reduced sample size required when using Consumer Confidence over the more widely-available growth measure.

\section{Exploring the Mechanism: Policy Regimes and Perceptions of Government Responsibility}

Pooled time-series analyses support our theoretical proposition that policy reforms condition economic accountability. By structuring the state's role in the economy, the policy regime in place affects the public's perceptions of responsibility for economic outcomes. At least in the eyes of the public, interventionist policies put presidents behind the wheel of the economy. Given such great responsibility, the public heaps credit on presidents for good times and severely punishes them for hard times. Conversely, to the public, neoliberalism places presidents in the back seat, 
reducing their role in and responsibility for the economy. Thus, the degree of perceived government control over economic conditions is ostensibly the mechanism through which the orientation of economic policy shapes political accountability. Is this mechanism empirically defensible?

Ideally, we would test the relationship between policy regimes and public perceptions of policy control over time. Data limitations prevent this. Regional surveys contain items related to policy preferences but none on perceptions of how policy works. As a second-best tack, we look at crosssectional data on perceptions of policy responsibility with the following question from the 2002 and 2003 Latinobarometer: "Given the economic problems in [country], from the following list of institutions and actors, which do you think are responsible?" Respondents could identify zero to nine actors on a closed list. Most frequent were "the government's economic policy" (57\% of respondents) and "the lack of entrepreneurial initiative" $(24 \%) .{ }^{10}$ From these responses, we create an ordered trichotomous variable, Blame Attribution coded 1 if the respondent identifies the government's economic policy as responsible, 2 if she blames lack of entrepreneurial initiative, and 3 if she assigns blame either other actors or if she blames both government and business for the state of the economy. ${ }^{11}$

To test our proposed mechanism, we model Blame Attribution as a function of Neoliberalism

\footnotetext{
${ }^{10}$ Other response categories are lack of individual initiative (20\%), lack of domestic goods (16\%), globalization (15\%), the IMF (15\%), banks (13\%), and the WTO (8\%). Data and documentation are available at http://www.latinobarometro.org.

${ }^{11}$ Removing the 12 percent of respondents who blamed both government policy and entrepreneurs does not alter our inferences.
} 
and Statism. If market orthodoxy reduces the penchant for citizens to attribute responsibility for the economy to the incumbent, then the effects of Neoliberalism on blaming government policy should be negative. In contrast, Neoliberalism should be positively associated with blaming economic problems on a lack of entrepreneurial initiative. Statism should carry the opposite effects, raising the likelihood of blaming government policies and lowering the likelihood of blaming business. Since the overall size of the domestic economy may affect perceptions of responsibility for economic conditions, we control for the natural log of GDP in real US dollars. We include individual-level controls for ideological congruence, education, socioeconomic status, gender, and age (Alcañiz and Hellwig 2011). ${ }^{12}$ Models are estimated using a generalized structural equation model with a multinomial link function and shared random effects (Grilli and Rampichini, 2007). ${ }^{13}$

Table 2 reports the results, with the "blame government policy" and "blame entrepreneurs" as the two reported response categories with "other actors" as the baseline. Briefly, note that model covariates perform as expected. For example, individuals who share the ideology of the government in power are less likely to blame the government's policy and more likely to cite entrepreneurs as responsible. And the larger the economy, the more likely individuals will blame business. With respect to our variables of interest, in the first column Neoliberalism's negative

\footnotetext{
${ }^{12}$ Government Ideology is scored 1 if respondent and president share a left/right ideological position. Education is a 7-point scale. Socioeconomic status is a 5-point, interviewer assessed scale.
}

${ }^{13}$ Specifically, we allow intercepts to vary across country and include a dummy variable indicating whether the survey was administered in 2002 or 2003. 
coefficient suggests that, on average, individuals in market orthodox regimes are less likely to attribute

Table 2. Neoliberalism and Blame Attributions, 17 Latin American Countries, 2002-2003

\begin{tabular}{|c|c|c|}
\hline & $\begin{array}{l}\text { Blame Government } \\
\text { Economic Policy }\end{array}$ & $\begin{array}{c}\text { Blame Lack of } \\
\text { Entrepreneurial Initiative }\end{array}$ \\
\hline \multicolumn{3}{|l|}{ Fixed Effects } \\
\hline Neoliberalism & $\begin{array}{c}-0.075 * * \\
(0.032)\end{array}$ & $\begin{array}{l}0.156^{* *} \\
(0.033)\end{array}$ \\
\hline Statism & $\begin{array}{l}-0.007 \\
(0.049)\end{array}$ & $\begin{array}{l}-0.208 * \\
(0.052)\end{array}$ \\
\hline $\operatorname{Ln}(G D P)$ & $\begin{array}{l}-0.012 \\
(0.033)\end{array}$ & $\begin{array}{c}0.082 * * \\
(0.034)\end{array}$ \\
\hline Government Ideology & $\begin{array}{l}-0.008 \\
(0.028)\end{array}$ & $\begin{array}{c}0.203 * * \\
(0.041)\end{array}$ \\
\hline Education & $\begin{array}{r}0.071 * * \\
(0.008)\end{array}$ & $\begin{array}{c}0.001 \\
(0.012)\end{array}$ \\
\hline Socio-Economic Status & $\begin{array}{l}0.033 * * \\
(0.013)\end{array}$ & $\begin{array}{l}0.100 * * \\
(0.020)\end{array}$ \\
\hline Female & $\begin{array}{c}0.060 * * \\
(0.023)\end{array}$ & $\begin{array}{c}-0.064 * * \\
(0.035)\end{array}$ \\
\hline Age $26-40$ & $\begin{array}{c}0.024 \\
(0.030)\end{array}$ & $\begin{array}{l}0.111^{*} \\
(0.047)\end{array}$ \\
\hline Age $41-60$ & $\begin{array}{c}-0.078 * * \\
(0.032)\end{array}$ & $\begin{array}{c}0.052 \\
(0.050)\end{array}$ \\
\hline Age 61 plus & $\begin{array}{c}-0.153 * * \\
(0.042)\end{array}$ & $\begin{array}{c}0.019 \\
(0.062)\end{array}$ \\
\hline Year & $\begin{array}{c}-0.465^{* *} \\
(0.090)\end{array}$ & $\begin{array}{c}0.018 \\
(0.094)\end{array}$ \\
\hline Constant & $\begin{array}{c}0.187 * * \\
(0.360)\end{array}$ & $\begin{array}{c}-2.739 * * \\
(0.380)\end{array}$ \\
\hline $\begin{array}{l}\text { Random Effects } \\
\text { Variance }\end{array}$ & $\begin{array}{c}0.060 * * \\
(0.016)\end{array}$ & \\
\hline $\begin{array}{l}\text { Log Likelihood } \\
\mathrm{N}\end{array}$ & $\begin{array}{c}-33501.91 \\
35146 \\
\end{array}$ & \\
\hline
\end{tabular}

Notes: The dependent variable is Blame Attribution, which is a categorical measured coded $3=$ "lack of entrepreneurial initiative," 2 = "government economic policy", 1 = neither/both, where "neither/both" is the baseline category. Cells report coefficients with standard errors in parentheses 
from estimating a generalized structural equation model with a multinomial link function and shared random effects. ${ }^{* *} \mathrm{p} \leq 0.05, * \mathrm{p} \leq 0.10$, two tailed test.

Source: Latinobarometer $2002 \& 2003$

Table 3. Probability of Blame Attribution, Counterfactual Scenarios

\begin{tabular}{|c|c|c|c|c|}
\hline \multicolumn{2}{|c|}{ Counterfactual scenario } & \multicolumn{3}{|c|}{ Probability of Blaming } \\
\hline $\begin{array}{c}\text { Neoliberalism } \\
\text { in-sample ptile } \\
\text { value }\end{array}$ & $\begin{array}{c}\text { Statism } \\
\text { in-sample ptile } \\
\text { value }\end{array}$ & $\begin{array}{l}\text { Government } \\
\text { Economic Policy }\end{array}$ & $\begin{array}{c}\text { Lack of } \\
\text { Entrepreneurial } \\
\text { Initiative }\end{array}$ & Difference \\
\hline $50^{\text {th }}$ & $50^{\text {th }}$ & 0.42 & 0.20 & 0.22 \\
\hline $90^{\text {th }}$ & $10^{\text {th }}$ & 0.36 & 0.23 & 0.14 \\
\hline $10^{\text {th }}$ & $90^{\text {th }}$ & 0.50 & 0.07 & 0.44 \\
\hline
\end{tabular}

Notes: Probabilities are produced from Table 2 estimates by manipulating Neoliberalism and Statism at their median, $90^{\text {th }}$, and $10^{\text {th }}$ percentile values while holding all other covariates at their mean or modal values.

responsibility for economic problems to the government's economic policy relative to the baseline category. In the second column, Neoliberalism has the opposite effect: it raises perceptions that entrepreneurial initiative — or private sector business activity — is to blame for poor economic conditions. And Statism's negative and significant coefficient in the second column suggests policy regimes that interfere with the market reduce individuals' tendencies to blame market actors.

Table 3 uses model estimates to illustrate the predicted probabilities of blaming the government in three counterfactual scenarios. The top row shows blame distribution in an "average" case, in which both policy regime measures are set to their median in-sample values. In this scenario, the “average" individual blames government policy with probability 0.42 and entrepreneurial activity with probability 0.20 . The second row provides a contrasting example under an orthodox economic policy regime (Neoliberalism high, Statism low). Relative to the "average" scenario, the average 
person is less like to target the government for blame than businesses. Lastly, the third row presents the inverse situation in which statist policies prevail. Consistent with expectations, we see a greater propensity to lay responsibility for economic conditions at the feet of government actors. While limits on survey data availability mean these results should be taken as preliminary, they are nonetheless consistent with our basic proposition that neoliberal policy regimes reduce economic accountability by weakening mass perceptions of government responsibility for observed outcomes.

\section{Conclusion}

As the pendulum swung from ISI statism to neoliberal orthodoxy, stalled development led observers to dub the 1980s as Latin America's "lost decade." The democracy that accompanied economic liberalization in much of the region seemed incapable of responding to citizen demands. Many wondered if neoliberalism was antithetical to the democratic ideals of responsiveness and accountability. After famously advocating for social and political reforms to enhance government responsiveness and accountability in neoliberal economies, a dejected Atilio Borón (1996) wryly noted, "There are no terms in Spanish or Portuguese that correspond to either 'responsiveness' or 'accountability"' (13). Even after Latin American leaders backed away from orthodoxy and embraced some of these very reforms, Noam Chomsky (2010) declared, "The very design of neoliberal principles is a direct attack on democracy" (47). Bold statements by influential voices grab our attention. Yet as intriguing as they are, we have thus far lacked a full accounting of the implications of distinct economic regimes for mass politics and, especially, for democratic accountability.

Moving from commentary to theory, we posit economic policy regimes influence economic 
accountability in two interrelated steps. First, policies that concentrate economic management in the government's hands should heighten the degree of responsibility the public assigns incumbent leaders for economic outcomes. Second, the extent to which the public evaluates political executives based on economic performance outcomes should depend on how much the state intervenes in how the economy works. Since more statist policy strategies overtly intervene in the economy, leaders in such regimes should be subject to greater scrutiny with regards to economic performance than leaders in neoliberal regimes, which diffuse economic management away from the (direct) control of the state. To test these claims, this study combines novel macro-level measures of economic policy orientations, subjective economic evaluations, and presidential approval with existing data on individual-level responsibility attributions in Latin America. The macro- and micro-level evidence marshaled in the foregoing analyses is extremely consistent with our theoretical framework.

Our results advance the larger debate on accountability (and responsiveness) over Latin America's dual transitions to markets and democracy with the most comprehensive demonstration to date that neoliberalism and accountability coexist uneasily. Statist models centralize economic decisions in the government's hand and, as such, better facilitate economic accountability by the public than liberal, market-oriented models. In reality, of course, no Latin American political economy fits either ideal type —all are heterodox mixtures. And in terms of how democracy works in practice, that may be good news. If Latin American voters indeed prefer modest state intervention and the choices markets provide (Baker, 2009; Baker and Greene, 2011), then mixed economic strategies may optimize the democratic ideals of responsiveness and accountability.

As such, our findings can help explain the electoral strength and resilience of the New Left in Latin America. If votes for the New Left represent a "performance mandate" to improve how 
markets function, rather than to replace them wholesale (Baker and Greene, 2011), then policies that increase protection from the market's negative externalities not only bolster government responsiveness but also infuse democratic politics in the region with greater economic accountability than witnessed during the neoliberal era. The result appears to be greater stability. Indeed, in the past decade only one (interim) president, Bolivia's Carlos Mesa, was ousted via mass protests over the economy. This track record is all the more impressive in the wake of the “new political instability" swept over Latin America in the 1990s and 2000s (Pérez-Liñán, 2007) and the inauspicious global economic conditions caused by the Great Recession.

Another implication of this study is that neoliberal policy regime removes politics from economics—or at least does so in the public's mind. So "going neoliberal" may help leaders decouple their public support from economic performance. On one hand, they can more credibly shift blame for poor performance but, on the other hand, they cannot fully reap the rewards of economic booms. In regimes which approximate statism, economics and politics are more tightly bound. Given that both pure statism and pure neoliberalism are unpalatable to citizens and, thus, carry unpalatable consequences for leaders who rely on public support, our study points to why today's heterodoxy is the dominant strategy. Moreover, if interventionist approaches are in fact more reliable paths to long-term development and equality (Huber and Stephens 2012), then Latin American political economy may be on the verge of a new equilibrium.

Finally, this study carries lessons beyond the Latin American experience that contribute to a more general understanding of how accountability for the economy works. Reward-punishment models of economic voting assume voters observe current conditions, ascribe them to the government's policy, and render judgment on their leaders. The threat of removal from office, the argument goes, provides even the most self-centered elites incentives to pursue welfare-enhancing 
policies and to grow the economy. Recent research, however, questions this assumption. Far from constant, the economy's salience in the minds of the electorate varies according to circumstance (Singer, 2011), and a growing number of studies highlight how elites manipulate the messages about the economy or shift their policies to modify the role economics plays in elections (Hart, 2013; Hellwig, 2012; Williams, 2015). Building on these insights, our study suggests that the choice of policy regime for economic development influences how publics associate economic conditions with policymaker decisions and how they, in turn, assign reward and blame. Findings presented here should encourage scholars to examine how reform options, economic duress, and political ambition weigh on the behavior of current and aspiring politicians and the publics they must court. 


\section{References}

Alcañiz, Isabella, and Timothy Hellwig. 2011. "Who’s to Blame? The Distribution of Responsibility in Developing Democracies. British Journal of Political Science 41: 389-411.

Arce, Moisés, and Paul T. Bellinger, Jr. 2007. 'Low-Intensity Democracy Revisited: The Effects of Economic Liberalization on Political Activity in Latin America.” World Politics 60(1):97-121.

Arce, M. E., \& Carrión, J. F. 2010. "Presidential support in a context of crisis and recovery in Peru, 1985-2008." Journal of Politics in Latin America 2(1):31-51.

Avelino, G., Brown, D. S., \& Hunter, W. 2005. “The Effects of Capital Mobility, Trade Openness, and Democracy on Social Spending in Latin America, 1980-1999.” American Journal of Political Science 49(3):625-641.

Baker, A. 2009. The Market and the Masses in Latin America: Policy Reform and Consumption in Liberalizing Economies. New York: Cambridge University Press.

Baker, A, \& Greene, K. F.. 2011. “The Latin American Left's Mandate: Free-Market Policies and Issue Voting in New Democracies." World Politics 63(1): 43-77.

Bellucci, P., \& Lewis-Beck, M. 2011. “A stable popularity function? Cross-national analysis.” European Journal of Political Research 50:190-211. 
Birdsall, N., \& Fukuyama, F. 2011. “The Post-Washington Consensus-Development after the Crisis." Foreign Affairs 90(2):45-53.

Borón, A. 1996. “Democracy or Neoliberalism?” Boston Review 21(5): 9-13.

Buendía, J. 1996. "Economic reform, public opinion, and presidential approval in Mexico, 19881993." Comparative Political Studies 29(5):566-591.

Campello, D., \& Zucco, Jr., C. 2016. "Presidential Success and the World Economy." The Journal of Politics 78(2):589-602.

Calvo, E. 2007. “The Responsive Legislature: Public Opinion and Law Making in a Highly Disciplined Legislature.” British Journal in Political Science 37(2):263-280.

Canes-Wrone, B. \& De Marchi, S. 2002. "Presidential Approval and Legislative Success." Journal of Politics 64(2):491-509.

Canes-Wrone, B., Herron, M. C., \& Shotts, K. W. 2001. "Leadership and Pandering: A Theory of Executive Policymaking." American Journal of Political Science 45(3):532-550.

Carlin, Ryan E., Gregory J. Love, and Cecilia Martinez-Gallardo. 2015. “Cushioning the Fall: Scandals, Economic Conditions, and Executive Approval.” Political Behavior. 37(1): 109-130. 
Chomsky, N. 2010. Hopes and Prospects. Chicago: Haymarket Books.

Corrales, J. 2016. “Can Anyone Stop the President? Power Asymmetries and Term Limits in Latin America, 1984-2016." Latin American Politics and Society 58(2):3-25.

De Ferrari, I. 2015. “The Successor Factor: Electoral Accountability in Presidential Democracies.” Comparative Political Studies 48(2):193-230.

Domínguez, J. I. 1998. “Free Politics and Free Markets in Latin America.” Journal of Democracy 9(4):70-84.

Echegaray, F., \& Elordi, C. 2001. Public Opinion, Presidential Popularity, and Economic Reform in Argentina. In S. C. Stokes, Public support for market reforms in new democracies (pp. 187214). New York: Cambridge University Press.

Erikson, R. S., MacKuen, M. B., \& Stimson, J. A. 2002. The Macro Polity. New York: Cambridge University Press.

Gélineau, F. 2007. “Presidents, Political Context, and Economic Accountability: Evidence from Latin America." Political Research Quarterly 60(3):415-428.

Gervasoni, C. 1999. "El impacto electoral de las reformas económicas en América Latina (19821995).” América Latina Hoy 22: 93-110. 
Grilli, L., \& Rampichini, C. 2007. “A Multilevel Multinomial Logit Model for the Analysis of Graduates’ Skills.” Statistical Methods and Applications 16: 381-393.

Hart, A. 2013. "Can Candidates Activate or Deactivate the Economic Vote? Evidence from Two Mexican Elections." Journal of Politics 75(4): 1051-1063.

Hellwig, Timothy. 2012. "Constructing Accountability: Party Position Taking and Economic Voting." Comparative Political Studies 45 (1):92-119.

Huber, E. \& Stephens, J. 2012. Democracy and the Left: Social Policy and Inequality in Latin America. Chicago: University of Chicago Press.

Im, K. S, Pesaran, M. H., \& Shin, Y. 2003 “Testing for Unit Roots in Heterogeneous Panels.” Journal of Econometrics 115(1):53-74.

Johnson, G. B., \&. Schwindt-Bayer, L A. 2009. "Economic Accountability in Central America." Journal of Politics in Latin America 1(3):33-56.

Kaplan, S. B. 2013. Globalization and Austerity Politics in Latin America. New York: Cambridge University Press. 
Kurtz, M. J., \& Brooks, S. M. 2008. “Embedding Neoliberal Reform in Latin America.” World Politics 60(2):231-280.

Levitsky, S., \& Roberts, K. M. 2011. “The Resurgence of the Left in Latin America.” Baltimore: Johns Hopkins University Press.

Lewis-Beck, M. S., Nadeau, R, \& Elias, A. 2008. "Economics, Party, and the Vote: Causality Issues and Panel Data.” American Journal of Political Science 52(1):84-95.

Lora, E. 2012. "Structural Reforms in Latin America: What Has Been Reformed and How to Measure It.” IDB Working Paper Series No. IDB-WP-346.

Manin, B., Przeworski, A., \& Stokes, S. C. 1999. Elections and Representation. In Przeworski, A., Stokes, S. C. \& Manin, B. (Eds.), Democracy, Accountability, and Representation, (pp. 2954). Cambridge, U.K.; New York: Cambridge University Press.

Martinez-Gallardo, C. 2012. "Out of the cabinet: what drives defections from the government in presidential systems?” Comparative Political Studies 45(1): 62-90.

Morgan Kelly, J. 2003. "Counting on the Past or Investing in the Future? Economic and Political Accountability in Fujimori’s Peru.” Journal of Politics 65(3):864-80.

Nickell, S. 1981. Biases in dynamic models with fixed effects. Econometrica, 49:1417-1426. 
O’Donnell, G. A. 1994. “Delegative Democracy.” Journal of Democracy 5(1):55-69.

Palmer, H. D., \& Whitten, G. D. 1999. “The electoral impact of unexpected inflation and economic growth.” British Journal of Political Science 29:623-639.

Pérez-Liñán, A. 2007. Presidential Impeachment and the New Political Instability in Latin America. New York: Cambridge University Press.

Plümper, T., \& Troeger, V. 2007. "Efficient Estimation of Time-Invariant and Rarely Changing Variables in Panel Data Analysis with Unit Effects." Political Analysis 15(2):124139.

Rosas, G., \& Manzetti, L. 2015. "Reassessing the Trade-Off Hypothesis: How Misery Drives the Corruption Effect on Presidential Approval.” Electoral Studies 39(Sept.): 26-38.

Ruggie, J. G. 1982. 'International Regimes, Transactions, and Change: Embedded Liberalism in the Postwar Economic Order.” International organization 36(2):379-415.

Samuels, D. J. 2004. "Presidentialism and Accountability for the Economy in Comparative Perspective." American Political Science Review 98(3):425-436.

Singer, M. M. 2011. "Who Says 'It's the Economy'? Cross-National and Cross-Individual 
Variation in the Salience of Economic Performance." Comparative Political Studies 44(3):284312.

Steinberg, D. A. 2017. "Interest Group Pressures and Currency Crises: Argentina in Comparative Perspective." Comparative Politics 50(1):61-82.

Steinberg, D. A., Koesel, K., \& Thompson, N. 2015. "Political Regimes and Currency Crises." Economics and Politics 27(3):337-61.

Stimson, J. A. 1991. Public Opinion in America: Moods, Cycles, and Swings. Boulder, CO: Westview Press.

Stokes, S. C. 2001. Mandates and Democracy: Neoliberalism by Surprise in Latin America. New York: Cambridge University Press.

Tripodis, Y., \& Zirogiannis, N. 2015. "Dynamic Factor Analysis for Multivariate Time Series: An Application to Cognitive Trajectories." International Journal of Clinical Biostatistics and Biometrics 1(1):1-8.

Weyland, K. G. 1996. "Risk taking in Latin American economic restructuring: Lessons from prospect theory.” International Studies Quarterly 40(2):185-207.

Weyland, K. G. 2004. "Neoliberalism and Democracy in Latin America: A Mixed Record," Latin American Politics and Society 46(1):135-157. 
Williams, L. K. 2015. "Elite Messages, Economic Conditions, and Retrospective Evaluations." Paper presented at the University of Sao Paulo, Brazil.

Williams, L. K., \& Whitten, G. D. 2011. "Dynamic Simulations of Autoregressive Relationships.” Stata Journal 11(4):577-588.

Zechmeister, E. J., \& Zizumbo-Colunga, D. 2013. "The varying political toll of concerns about corruption in good versus bad economic times." Comparative Political Studies 46(10):11901218. 